\title{
TRUMPETER SWANS IN THE CYPRESS HILLS
}

\author{
by Dan Nieman, Canadian Wildlife Service, Saskatoon
}

The Trumpeter Swan (Olor buccinator), the largest waterfowl in the world, once ranged as a breeding bird from Alaska and Arctic Canada south to Iowa and Missouri and east to Indiana (Banko and Mackay, 1964). Unable to adapt to the encroachment of civilization, these magnificent birds were virtually eliminated from most of their former range by overhunting and destruction of breeding habitat (Taverner, 1949; Banko, 1960). By the early years of this century, Trumpeters were near extinction. Although small, unreported groups may have existed in remote parts of British Columbia and Alaska, it was thought that there were only several dozen in the wild by 1916 (Munro, 1962).

Trumpeter Swans have staged a comeback in several areas: they have been protected throughout North America and have bred in captivity in Canada and the United States. Surveys of breeding and wintering grounds indicate that the total continental population was approximately 1,500 by 1961 and likely exceeds 4,000 at present (Evenden, 1969). The Trumpeter Swan's survival in North America is probably assured, but the species may never become abundant.

Trumpeter Swans are no longer listed as endangered species in Canada, but are still relatively rare. Here, they are restricted to British Columbia, Alberta and Saskatchewan. In the United States they are found in scattered localities in several northwestern states and in southern Alaska.

About one-half of the world's population of Trumpeters winters in British Columbia. The largest concentration (450) is located on Lonesome Lake, approximately 240 miles north of Vancouver. Other wintering populations are present on the north haif of Vancouver Island and on the Queen Charlotte Islands (Morris, 1971). Small numbers winter in northcentral British Columbia where fast streams and warm springs keep the water from freezing. There have been no substantiated reports of Trumpeters breeding in British Columbia. A fairly stable population of about 100 birds, including from 15 to 30 breeding pairs, resides near Grande Prairie in the Peace River District of Alberta (Banko and Mackay, 1964). Another one or two pairs have occasionally nested near Brooks, Alberta.

\section{The Trumpeter Swan in Saskatchewan}

A small population breeding in the Cypress Hills region of southwestern Saskatchewan comprises a tiny part of the continental population. As the species is relatively rare, this local, isolated breeding population - thought to be the only one in the province is important.

Trumpeter Swans may have been first reported in Saskatchewan in 1914, when one pair was observed on Cypress Lake (Symons, 1967). Lister (1951) reported a breeding pair with a brood each year, from 1948 through 1950 , on the Alberta side of the Cypress Hills, approximately three miles from the Saskatchewan border. But Trumpeter Swans were not reported as breeders in Saskatchewan until 1953, when Bard (1953) saw one pair with a brood in the Cypress Hills. No expansion of the population was reported until a family group of nine birds (two breeding pairs, three cygnets and two nonbreeding adults) was located in 1961 (Lahrman, 1961). The breeding population dropped to one pair in 1962 and remained at that level until 1966, when two pairs nested in the area (N. Knowles, pers. comm.).

\section{Methods and Objectives}

On July 20-21, 1971, accompanied by H. J. Poston of the Canadian Wildlife Service, and Cpl. N. Knowles of the Royal Canadian Mounted Police, I conducted an extensive ground and aerial survey to determine 
the number of Trumpeter Swans breeding in the Cypress Hills and to delineate their individual breeding areas. We also made a special effort to locate non-breeding Trumpeters which are thought to return to their rearing areas until they attain breeding age, believed to be four years (Banko, 1960).

\section{Results}

We found 16 Trumpeter Swans: three breeding pairs, one adult nonbreeder, two broods of two cygnets each and one of five cygnets. From an average clutch of five to six eggs, only two or three cygnets survive to migrate south in the fall (Banko and Mackay, 1964).

All of the breeding territories were located within the boundaries of the Cypress Hills Provincial Forest and Park, Saskatchewan. The lone adult was outside the park boundaries.

\section{Discussion}

The breeding population of Trumpeter Swans in the Cypress Hills of Saskatchewan remained at one pair until 1961 when an additional family group was observed. In 1971, an intensive survey of the area revealed a total of 16 birds, including three breeding pairs. This is the highest population yet reported in the Cypress Hills.

The size of the Cypress Hills population of Trumpeter Swans has not increased greatly in recent years. The reasons are not clear, but further growth of the population may be restricted by a shortage of the proper habitat and high cygnet mortality. Cygnet mortality from accidents, parasites and disease has been reported high in other areas (Banko

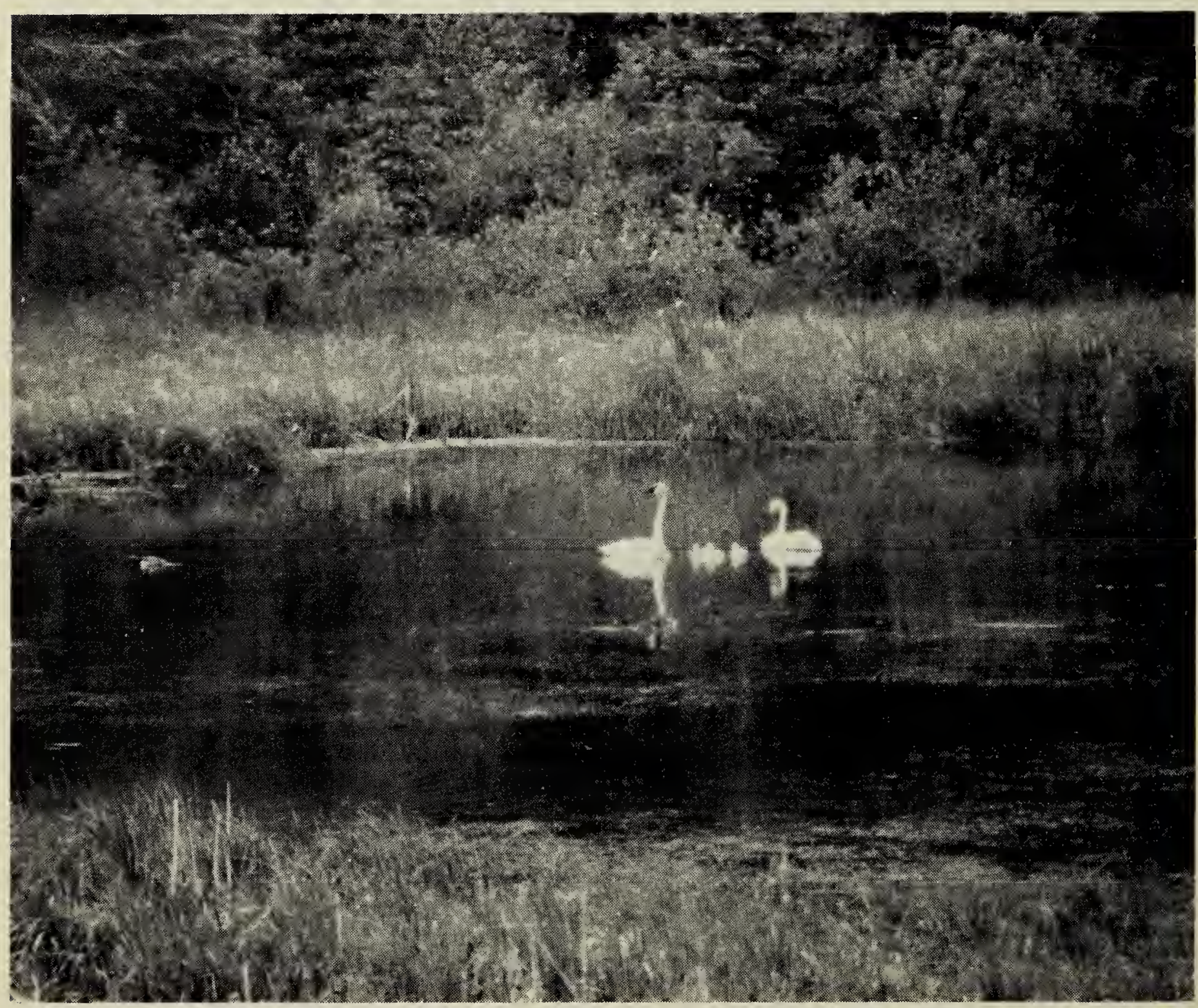

Trumpeter Swans in Cypress Hills, Saskatchewan.

Photo by Fred W. Lahrman, Museum 
and Mackay, 1964). Fledged cygnets from the Cypress Hills flock have been shot in the past, a fact which could be an important factor in survival. If brood mortality was not excessive, one would expect to find more non-breeders - cygnets which have homed to their rearing areas and have not yet reached breeding age.

The Cypress Hills Trumpeter Swans require, as they do in other areas, large breeding territories with a maximum of one pair on each lake. Some of the lakes are quite large, but the Trumpeters are so aggressive they will chase other swans and geese from their breeding areas. They will tolerate ducks, however (Delacour, 1954). While other suitable breeding areas may exist in the park, they are not enough to provide nesting habitat for many more swans - probably no more than 10 or 12 breeding pairs. The nests are usually located on muskrat houses in stands of emergent cattail and bulrush vegetatation ( $R$. Mackay, pers. comm.).

Further research and management are needed if the breeding population of wild Trumpeter Swans in Saskatchewan is to be preserved. The loss of even one nesting territory or breeding pair will seriously jeopardize the survival of this small group. An evaluation of the breeding biology and habitat requirements and determination of the migration routes and wintering grounds of this flock could help preserve this remnant of a rare waterfowl species in Saskatchewan.

\section{Acknowledgments}

I wish to gratefully acknowledge the technical and field assistance of H. J. Poston, Canadian Wildlife Service. N. Knowles, Royal Canadian Mounted Police, directed us to breeding areas and his intimate knowledge of the terrain was a great asset to the survey. Special thanks go to the R.C.M.P. for providing an aircraft for the aerial survey. I also want to thank R. H. Mackay and J. B. Gollop, Canadian Wildlife Service, both of whom critically reviewed the manu- script and provided helpful suggestions.

\section{LITERATURE CITED}

Banko, W E. 1960. The Trumpeter Swan. North Ämerican fauna, 63 . U.S. Dept. Interior, Washington. $214 \mathrm{pp}$.

Banko, W. E., and R. H. Mackay. 1964. Our native swans. In Waterfowl Tomorrow. U.S. Dept. Interior, Washington, $770 \mathrm{pp}$.

Bard, F.C. 1953. The Trumpeter Swan. Blue Jay, $11: 26-27$.

Delacour, J. 1954. The waterfowl of the world. Vol. 1. Country Life Ltd., London. $284 \mathrm{pp}$.

Evenden, F. G. 1969. Report of Committee on Conservation, 1969. Auk, $86: 738-744$.

Lahrman, F. W. 1961. A second pair of Trumpeter Swans nesting in Saskatchewan. Blue Jay, $19: 18-19$.

Lister, R. 1951. 'Trumpeter Swans breeding in the Cypress Hills of Alberta. Can. Field Nat., $65: 157-158$.

Morris, W. A. 1971. Birds of Bxitish Columbia. In Canadian Wildlife Service '71. Canadian Wildlife Service, Ottawa. 88 pp.

Munro, D. A. 1962. Trumpeter Swans. Canadian Audubon, 24 :65-69.

Symons, R. D. 1967. Hours and the birds. Univ. of Toronto Press, Toronto. $224 \mathrm{pp}$.

Taverner. P. A. 1949. Birds of Canada. The Musson Book Co., Ltd., Toronto. $447 \mathrm{pp}$.

\section{ALBINO MALLARD NESTS AT WATERHEN MARSH}

\author{
by R. Kent Brace,
}

306 - 4725 Albert St., Regina

During 1970 and 1971, a partial albino fernale Mallard (Anas platyrhynochos) twice nested on a 5.9 acre island in the centre of Waterhen Marsh (Lat. N. 52 $51^{\prime}$ Long. W. $\left.105^{\circ} 02^{\prime}\right)$ near Kinistino, Saskatchewan.

The bird's plumage was white except on the breast, the upper part of the back and the speculum. The feet and bill were bright orange.

In both years the duck nested in a dense stand of snowberry (Symphoricarpos sp.), the second nest being approximately 50 feet from the first.

In mid-April 1971, the duck was paired with a normal Mallard drake; in 1970 , the mate was not observed.

Clutches of seven and eight eggs were laid in the two seasons. Five of seven hatched in 1970, and all eight eggs hatched in 1971. The 1970 brood was not observed; however, the 1971 brood was sighted-the young downy ducklings showed no apparent signs of albinism. 